\title{
Use of lac regulatory elements for gene expression in Lactobacillus casei
}

\author{
María José Gosalbes, Isabel PÉREZ-Arellano, \\ Carlos David Esteban, José Luis Galán, Gaspar Pérez-MartineZ* \\ Departamento de Biotecnología, Instituto de Agroquímica y Tecnología de Alimentos, \\ 46100-Burjassot, Valencia, Spain
}

\begin{abstract}
The lactose operon, lacTEGF, of Lactobacillus casei ssp. casei ATCC393 [pLZ15-] is encoding an antiterminator protein (LacT), the elements (LacE and LacF) of the lactose-specific phosphotransferase system (PTS) and a phospho- $\beta$-galactosidase (LacG). The lac operon is repressed by glucose and fructose and is induced by lactose, through the PTS/CcpA signal transduction system and an antiterminator mechanism, respectively. Furthermore, the antiterminator activity of LacT is also negatively modulated possibly by a PTS-mediated phosphorylation event. These strong regulatory mechanisms have been used in this work for the design of expression systems. Hence, Bacillus licheniformis $\alpha$-amylase has been efficiently expressed from pIA $\beta 5$ lacamy on lactose grown cells. Furthermore, a food-grade mutant, expressing Lactococcus lactis acetohydroxy acid synthase genes $(i l v B N)$, was obtained with an integrative system, developed using $l a c G$ and $l a c F$ as homologous sequences for recombination. As a result, $i l v B N$ genes were integrated in tandem between $l a c G$ and $l a c F$ in the chromosome and were co-ordinately expressed with the genes of the lactose operon.
\end{abstract}

Lactobacillus / lactose expression system / replicative vector / integrative vector

Résumé - Usage des éléments régulateurs de l'opéron lactose pour l'expression de gènes chez Lactobacillus casei. Les gènes du lactose Lactobacillus casei ssp. casei ATCC393 [pLZ15'] sont regroupés dans un même opéron, lacTEGF, codant pour un antiterminateur (LacT), pour les éléments spécifiques du transport du lactose par le système phosphotransferase dépendant du phosphoénolpyruvate (PTS) (LacE et LacF) et pour une phospho- $\beta$-galactosidase (LacG). L'opéron lac est soumis à une répression par le glucose et le fructose via le système de transduction de signal PTS/CcpA et à une induction par le lactose au moyen d'un mécanisme d'antiterminaison. De plus, l'activité de l'antiterminateur est aussi négativement modulée possiblement par un événement de phosphorylation étant impliqué le PTS. Dans ce travail, on a utilisé ces mécanismes régulateurs pour la construction de systèmes d'expression. Avec le vecteur pIAß5lacamy, on a obtenu l'expression de l' $\alpha$-amylase de Bacillus licheniformis à partir des éléments régulateurs de l'opéron lactose. On a aussi construit un vecteur intégratif utilisant les gènes $l a c G$ et $l a c F$ comme séquence homologue

* Correspondence and reprints

Tel.: (34) 96 3900022; fax: (34) 96 3636301; e-mail: gaspar.perez @ iata.csic.es 
pour la recombinaison. Les gènes ilvBN qui codent pour l'acétohydroxyacide synthétase de Lactococcus lactis ont été intégrés dans le chromosome de $L$. casei entre les gènes $l a c G$ et lacF et dans les mutants alimentaires obtenus, l'expression des gènes $i l v B N$ est donc coordonnée avec ceux de l'opéron lactose.

Lactobacillus / système d'expression du lactose / vecteur replicatif / vecteur intégratif

\section{INTRODUCTION}

\subsection{Gene expression and food-grade systems in lactic acid bacteria}

A number of heterologous genes have been expressed in lactobacilli with different constitutive promoters, with or without secretion signals $[11,15,17,22,32,37]$. However, more efficient expression systems have been developed for Lactococcus lactis that used different marker genes and regulatory elements [9]. Recently, a very remarkable system has been designed based on the inducible promoter of the nisin operon from L. lactis [31], that could be efficiently transferred to other lactic acid bacteria (LAB), including Lactobacillus [18]. Its regulation required the activity of the gene products of nisK and nisR, elements of a twocomponent-regulatory system induced by the antimicrobial peptide, nisin. This fact could represent an operative difficulty because previous chromosomal integration of nisK and nisR or a two-plasmid system was required.

Ideally gene expression systems for LAB should also consider the use of food-grade markers. There is a reduced number of interesting examples, such as the use of the sucrose utilisation genes as dominant marker in an integrative vector to achieve amplification of the desired foreign genes in the chromosome of Lactococcus lactis [19]. Other food-grade selection mechanisms have been developed where specific mutations in the host chromosome were complemented. An example of this complementation could be the system where an ochre supressor tRNA rescued a nonsense mutation in the chromosomal purine genes that are required for the growth on milk of L. lactis [8]. Also, lactose utilisation genes were chosen for this purpose and different vectors have been constructed using $l a c F$ and the lac promoter from the lactose operon of L. lactis [23, 28].

Genetic integration of desired genes can also provide safe food-grade expression systems. A direct way to achieve it is the use of randomly cloned chromosomal fragments or specific genes, such as $c d h$, as integration target [16, 21, 33]. In a more sophisticated mechanism of integration, a phage integrase-mediated site-specific insertion has been used [4, 24]. In the case of Streptococcus thermophilus, a system has been developed to integrate reporter genes between $l a c S$ and $l a c Z$ and they were consequently induced by lactose [25]. However, there are no examples of studies that used natural regulatory mechanisms in lactobacilli for the expression of heterologous proteins.

\subsection{Lactose operon of Lactobacillus casei}

In Lactobacillus casei ATCC393 [pLZ15 $]$, the lactose genes are grouped in a cluster transcribed as single operon, but it does not include the genes of the tagatose6-P pathway, as occurs in other lac operons described [1-3, 10, 13, 29]. The cluster lacTEGF encodes an antiterminator protein (LacT), lactose-specific elements (LacE and $\mathrm{LacF}$ ) of the phosphotransferase system (PTS) and a phospho- $\beta$-galactosidase (LacG) (Fig. 1). The promoter region contains a 


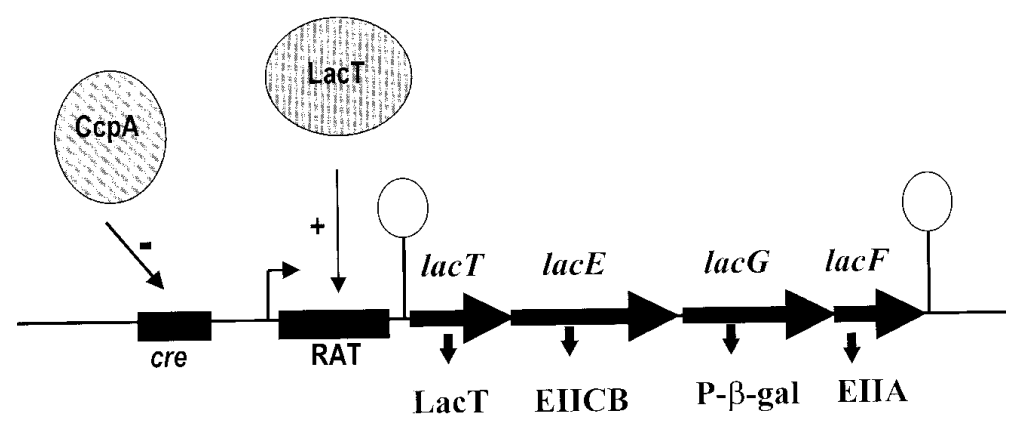

Figure 1. Genetic organisation of the lactose operon in Lactobacillus casei and proteins involved in its regulation (LacT and CcpA).

cre element (catabolite responsive element) overlapping the -35 region, which is followed by a highly conserved sequence, the ribonucleic antiterminator (RAT) sequence, and a terminator structure. In fact, it has been shown that the expression of the lac operon in L. casei ATCC393 [pLZ15-] is subject to dual regulation: carbon catabolite repression (CR) and induction by lactose through transcriptional antitermination $[14,26]$. This induction mechanism is remarkably different from the system found in the lac operon from L. lactis, where gene expression is controlled by the repressor LacR, with tagatose-6-phosphate as the likely inducer [10]. The above-mentioned $\mathrm{CR}$ of the lac operon is mediated by the general regulatory protein, CcpA, possibly by binding to the cre element at the lactose promoter (plac). Furthermore, the antiterminator activity of LacT is also negatively controlled by glucose, possibly by PTS-mediated phosphorylation as explained below [14]. Antiterminator proteins of the $\mathrm{BglG}$ family, such as LacT, share three common domains: an RNA binding domain and two PTS regulated domains (PRD-I and PRD-II) $[30,35,36]$. According to the proposed model of PTS-mediated control of PRDcontaining antiterminators, LacT would exist in three forms: (i) active (inducing lac operon), when PRD-I is dephosphorylated and PRD-II phosphorylated; (ii) inactive (non-induced), when both domains are phosphorylated; and (iii) inactive, when PRD-II is dephosphorylated, possibly by HPr, which occurs in the presence of glucose and could be considered as a secondary CR mechanism.

As a consequence of the studies on its genetic regulation, the lactose operon is the best-characterised gene cluster in $L$. case $i$ $[1-3,13,14,26,29]$. Due to the mentioned regulatory mechanisms controlling the lactose operon of L. casei, this system is highly inducible on lactose, but altogether, it is totally turned down when glucose is added as carbon source. Thus, it has been used to construct replicative and integrative vectors in Lactobacillus casei that allowed the achievement of the expression of heterologous proteins from the lactose promoter. This system has provided a useful tool that can be used for strain improvement of Lactobacillus casei in fermentation processes and a variety of new applications.

\section{RESULTS}

\subsection{Lactose induction from a shuttle plasmid: expression of Bacillus licheniformis $\alpha$-amylase in Lactobacillus casei}

The lac promoter region (EMBL accession number Z80834) which includes the regulatory elements (cre, RAT and terminator 
structure) could be amplified with primers lac11 (5'-TAGCACTGATCATTAAA-3') and lac33 (5'-TTGCACTGGGAGGGGAT-3') using the chromosomal DNA of Lactobacillus casei ATCC393 [pLZ15] as template.

The structural part of Bacillus licheniformis $\alpha$-amylase gene and a L. lactis secretion signal sequence were amplified by PCR from pGAL9 plasmid using AL93 (5'AATGAGAGCATTAATGTTTC) and AMIR2 (5'TCAACTTAAGTCGACGTCCTT CCTGAGGGC) $[27,38]$. This DNA fragment

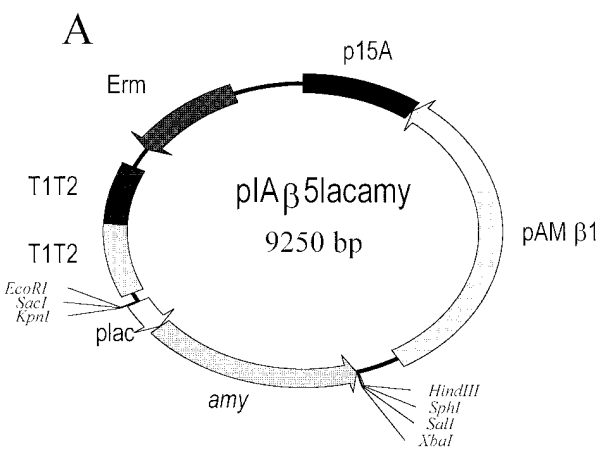

B

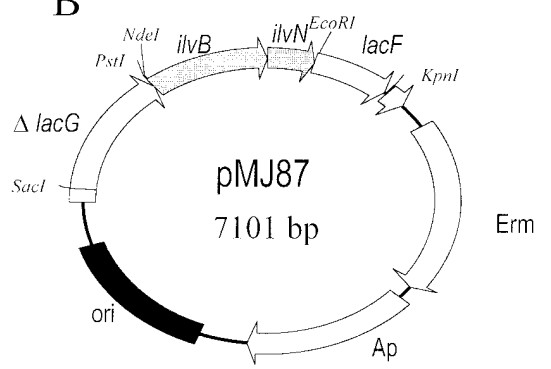

Figure 2. Restriction maps of replicative and integrative vectors. (A) Replicative vector: $a m y$ gene encodes $\alpha$-amylase from Bacillus licheniformis, Erm represents erythromycin-resistance gene, the lactose promoter is indicated as plac, T1T2 represent transcriptional terminators, $\mathrm{p} 15 \mathrm{~A}$ and pAM $\beta 1$ correspond to E. coli and Enterococcus replicons. (B) Integrative vector: $i l v B N$ genes encode the catalytic and regulatory subunits of acetohydroxy acid synthase, respectively, Erm and Ap are erythromycin and ampicillinresistance genes, ori represents E. coli replicon. was cloned in plasmid pIA $\beta 5$ under the promoter of the lac operon from $L$. case $i$ (Fig. 2A). The shuttle vector pIA $\beta 5$ is derived from pIL253 [34] and contains p15A replicon from pACYC184 [5] and the lacZ-T1T2 terminators cassette from pJDC9 [6]. The resulting plasmid pIA $\beta 5$ lacamy was used to transform $L$. case $i$ and one transformant was selected for further studies. Then, L. casei [pIA $\beta 5$ lacamy] was grown on ribose, lactose or glucose + lactose, and the production of $\alpha$-amylase was quantified from the supernatants with Phadebas amylase test (Pharmacia and Upjohn). The results obtained indicated that $\alpha$-amylase expression was clearly induced by lactose and repressed when glucose was present, following the expected expression pattern of the lac operon (Tab. I).

The genes coding for other proteins, such as GFP and $\beta$-glucuronidase, have also been cloned under lac promoter and displayed the same pattern of expression (data not shown).

\subsection{Food-grade integration system in Lactobacillus casei: expression of Lactococcus lactis ilvBN genes}

In Lactobacillus, chromosomal integration can be achieved by Campbell-like recombination events through DNA cloned in a non-replicating plasmid, which is homologous to the integration target, normally a chromosomal gene. An integrative

Table I. $\alpha$-amylase activity $\left(\mathrm{U} \cdot \mathrm{L}^{-1}\right.$ ) detected in $L$. case $i$ transformed with pIA $\beta 5$ and pIAß5lacamy.

\begin{tabular}{lcc}
\hline & pIA $\beta 5$ & pIA $\beta$ 5lacamy \\
\hline Ribose & ND & $0.65 \pm 0.077$ \\
Lactose & ND & $13.244 \pm 0.577$ \\
Glucose + lactose & ND & ND \\
\hline
\end{tabular}

ND, not detectable. The values and standard deviations are from at least 3 independent experiments. 
Figure 3. Diacetyl production by the wild-type (1) and ilvBN integrant (2) from glucose + lactose (black), lactose (white) and ribose (grey) grown cells.

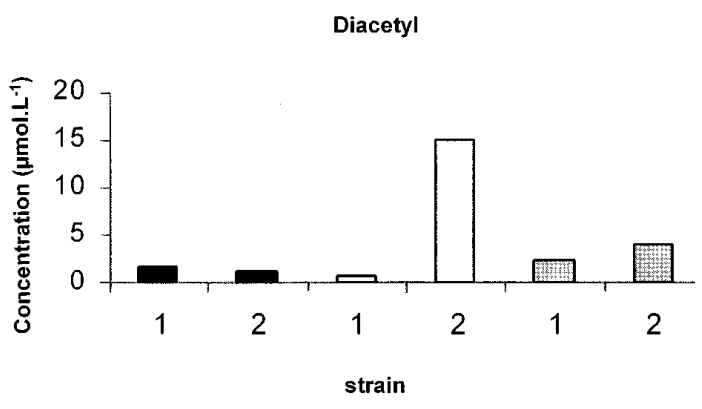

was selected and grown for two hundred generations in liquid medium without antibiotic. Colonies that had undergone a second recombination event (through the cloned lac $G$ fragment) suffered the excision of the vector giving rise to $\mathrm{Erm}^{\mathrm{s}} \mathrm{Lac}^{+}$colonies which had integrated the $i l v B N$ genes in the lac operon. A double recombinant (Erms and $\mathrm{Lac}^{+}$) of L. casei, designated as MJ146, was selected for further analysis. This strain showed an expression pattern of P- $\beta$-gal activity similar to that of the wild-type strain, it was induced by lactose and repressed by glucose (data not shown). Therefore, the insertion of $i l v B N$ did not interfere with the normal expression of the lac operon. Diacetyl production by the wild-type and mutant strains has been analysed as described previously [7] in a resting cell system, using bacterial cells that had been grown on ribose, lactose and glucose + lactose. A very high production of this metabolite could be detected when ilvBN integrant was grown on lactose, if compared with the other carbon sources (Fig. 3). This indicated that a new and very efficient system has been accomplished for the production of diacetyl in $L$. casei, where ilvBN genes from L. lactis are coordinately expressed with the lac genes.

\section{CONCLUSION}

A useful tool has been designed using the regulatory elements of the lac operon in a multicopy plasmid to express heterologous 
proteins in $L$. casei in a controllable way, induced by lactose and strongly repressed by glucose. In addition, a chromosomal insertion system has been developed to facilitate the integration of any gene in the lactose operon, that would be expressed following its regulation pattern. This system could easily be applied to industrial settings, since its inducer, lactose, is the main sugar in milk and milk whey. This integration system can be considered a self-cloning procedure, for which, depending on the country, genetically modified lactobacilli obtained through this process could be more easily accepted for industrial trials.

\section{ACKNOWLEDGMENTS}

This work was financed by the EU project BIO4-CT96-0380 and by funds from the Spanish CICyT (Interministerial Commission for Science and Technology) (Ref. ALI 98-0714). I. P.-A. was supported by a grant from the Consellería de Educación y Ciencia de la Generalitat Valenciana. C.D. E. and J.L. G. were the recipients of a fellowship from the Spanish government.

\section{REFERENCES}

[1] Alpert C.-A., Chassy B.M., Molecular cloning and nucleotide sequence of the factor III ${ }^{\text {lac }}$ gene of Lactobacillus casei, Gene 62 (1988) 277-288.

[2] Alpert C.-A., Chassy B.M., Molecular cloning and DNA sequence of $l a c E$, the gene encoding the lactose-specific enzyme II of the phosphotransferase system of Lactobacillus casei, J. Biol. Chem. 265 (1990) 22561-22568.

[3] Alpert C.-A., Siebers U., The lac operon of Lactobacillus casei contains lacT, a gene coding for a protein of BglG family of transcriptional antiterminators, J. Bacteriol. 179 (1997) 1555-1562.

[4] Alvarez M.A., Herrero M., Suárez J.E., The sitespecific recombination system of Lactobacillus species bacteriophage A2 integrates in Grampositive and Gram-negative bacteria, Virology 250 (1998) 185-193.

[5] Chang A.C.Y., Cohen S.N., Construction and characterization of amplifiable mutlticopy DNA cloning vectors derived from p15A cryptic miniplasmid, J. Bacteriol. 134 (1978) 1141-1156.

[6] Chen J.-D., Morisson D.A., Construction and properties of a new insertion vector, pJDC9, that is protected by transcriptional terminators and useful for cloning of DNA from Strepto coccus pneumoniae, Gene 64 (1988) 155-164

[7] Dauneau P., Pérez-Martínez G., Fractional factorial and multiple linear regression to optimise extraction of volatiles from a Lactobacillus plantarum bacterial suspension using purge and trap, J. Chromatogr. A 775 (1997) 225-230.

[8] Dickely F., Nilsson D., Hansen E.B., Johansen E., Isolation of Lactococcus lactis non suppressors and construction of food-grade cloning vector, Mol. Microbiol. 15 (1995) 839-847.

[9] de Vos W.M., Safe and suitable system for foodgrade fermentations by genetically modified lactic acid bacteria, Int. Dairy J. 9 (1999) 3-10.

[10] de Vos W.M., Vaughan E.E., Genetics of lactose utilization in lactic acid bacteria, FEMS Microbiol. Rev. 15 (1994) 217-237.

[11] Gobbetti M., Corsetti A., Morelli L., Elli M., Expression of $\alpha$-amylase gene from Bacillus stearothermophilus in Lactobacillus sanfrancisco, Biotechnol. Lett. 18 (1996) 969-974.

[12] Godon J.-J., Chopin M.-C., Ehrlich S.D., Branched-chain amino acid biosynthesis genes in Lactococcus lactis subsp. lactis, J. Bacteriol. 174 (1992) 6580-6589.

[13] Gosalbes M.J., Monedero V., Alpert C.-A., Pérez-Martínez G., Establishing a model to study the regulation of the lactose operon in Lactobacillus casei, FEMS Microbiol. Lett. 148 (1997) 83-89.

[14] Gosalbes M.J., Monedero V., Pérez-Martínez G., Elements involved in catabolite repression and substrate induction of lactose operon in $\mathrm{Lac}$ tobacillus casei, J. Bacteriol. 181 (1999) 3928-3934.

[15] Heng N.C.K., Jenkinson H.F., Tannock G.W., Cloning and expression of an endo-1,3-1,4- $\beta$ glucanase gene from Bacillus macerans in Lactobacillus reuteri, Appl. Environ. Microbiol. 63 (1997) 3336-3340.

[16] Hols P., Ferain T., Garmyn D., Bernard N., Delcour J., Use of homologous expression-secretion signals and vector-free stable chromosomal integration in engineering of Lactobacillus plantarum for $\alpha$-amylase and levanase expression, Appl. Environ. Microbiol. 60 (1994) 1401-1413.

[17] Hols P., Slos P., Dutot P., Reymund J., Chabot P., Deplace B., Delcour J., Mercenier A., Efficient secretion of the model antigen M6-gp41E in Lactobacillus plantarum NCIMB 8826 , Microbiology 143 (1997) 2733-2741.

[18] Kleerebezem M., Beerthuyzen M.M., Vaughan E.E., de Vos W.M., Kuipers O.P., Controlled gene expression systems for lactic acid bacteria: transferable nisin-inducible expression cassettes for Lactococcus, Leuconostoc, and Lactobacillus spp., Appl. Environ. Microbiol. 63 (1997) 4581-4584. 
[19] Leenhouts K., Bolhuis A., Venema G., Kok J., Construction of a food-grade multicopy integration system in Lactococcus lactis, Appl. Microbiol. Biotechnol. 49 (1998) 417-423.

[20] Leloup L., Ehrlich S.D., Zagorec M., MorelDeville F., Single crossing-over integration in the Lactobacillus sake chromosome and insertional inactivation of the pts and the lacI genes, Appl Environ. Microbiol. 63 (1997) 2117-2123.

[21] Lin M.-Y., Harlander S., Savaiano D., Construction of an integrative food-grade cloning vector for Lactobacillus acidophilus, Appl. Microbiol. Biotechnol. 45 (1996) 484-489.

[22] Maassen C.B.M., Laman J.D., den BakGlashouwer M.J.H., Tielen F.J., van HoltenNeelen J.C.P.A., Hoogteijling L., Antonissen C., Leer R.J., Pouwels P.H., Boersma W.J.A., Shaw D.M., Instruments for oral disease-intervention strategies: recombinant Lactobacillus casei expressing tetanus toxin fragment $\mathrm{C}$ for vaccination or myelin proteins for oral tolerance induction in multiple sclerosis, Vaccine 17 (1999) 2117-2128.

[23] MacCormick C.A., Griffin H.G., Gasson M.J., Construction of a food-grade host/vector system for Lactococcus lactis based on lactose operon, FEMS Microbiol. Lett. 127 (1995) 105-109.

[24] Martin M.C., Alonso J.C., Suárez J.E., Alvarez M.A., Generation of food-grade recombinant lactic acid bacterium strains by site-specific recombination, Appl. Environ. Microbiol. 66 (2000) 2599-2604.

[25] Mollet B., Knol J., Poolman B., Marciset O., Delley M., Directed genomic integration, gene replacement, and integrative gene expression in Streptococcus thermophilus, J. Bacteriol. 175 (1993) 4315-4324.

[26] Monedero V., Gosalbes M.J., Pérez-Martínez G., Catabolite repression in Lactobacillus case ATCC 393 is mediated by CcpA, J. Bacteriol. 179 (1997) 6657-6664.

[27] Pérez-Martínez G., Kok J., Venema G., van Dijl J.M., Protein export elements from Lactococcus lactis, Mol. Gen. Genet. 234 (1992) 401-411.

[28] Platteeuw C., van Alen-Boerrigter I., van Schalkwijk S., de Vos W.M., Food-grade cloning and expression systems for Lactococcus lactis, Appl. Environ. Microbiol. 62 (1996) 1008-1013.
[29] Porter E.V., Chassy B.M., Nucleotide sequence of the $\beta$-D-phospho-galactosidase gene of $\mathrm{Lac}$ tobacillus casei: comparison to analogous $p b g$ genes of other Gram-positive organisms, Gene 62 (1988) 263-276.

[30] Rutberg B., Antitermination of transcription of catabolic operons, Mol. Microbiol. 23 (1997) 413-421.

[31] Ruyter P.G.G.A., Kuipers O., de Vos W.M., Controlled gene expression systems for Lactococcus lactis with the food-grade inducer nisin, Appl. Environ. Microbiol. 62 (1996) 3662-3667.

[32] Scheirlinck T., De Meutter J., Arnaut G., Joos H., Claeyssens M., Michiels F., Cloning and expression of cellulase and xylanase genes in Lactobacillus plantarum, Appl. Microbiol. Biotechnol. 33 (1990) 534-541.

[33] Scheirlinck T., Mahillon J., Joos H., Dahese P., Michiels F., Integration and expression of $\alpha$-amylase and endoglucanase genes in the Lactobacillus plantarum chromosome, Appl. Environ. Microbiol. 55 (1989) 2130-2137.

[34] Simon D., Chopin A., Construction of a vector plasmid family and its use for molecular cloning in Streptococcus lactis, Biochimie 70 (1988) 559-566.

[35] Stülke J., Arnaud M., Rapoport G., MartinVerstraete I., PRD- $\alpha$ protein domain involved in PTS-dependent induction and carbon catabolite repression of catabolic operons in bacteria, Mol. Microbiol. 28 (1998) 865-874.

[36] Tortosa P., Aymerich S., Lindner C., Saier M.H Jr., Reizer J., Le Coq D., Multiple phosphorylation of SacY, a Bacillus subtilis antiterminator negatively controlled by the phosphotransferase system, J. Biol. Chem. 272 (1997) 17230-17237.

[37] Wanker E., Leer R.J., Pouwels P.H., Schwab H., Expression of Bacillus subtilis levanase gene in Lactobacillus plantarum and Lactobacillus casei, Appl. Microbiol. Biotechnol. 43 (1995) 297-303.

[38] Yuuki T., Nomura T., Tezuka H., Tsuboi A., Yamagata H., Tsukagoshi N., Udaka S., Complete nucleotide sequence of a gene coding for heat-and $\mathrm{pH}$-stable $\alpha$-amylase of Bacillus licheniformis: Comparison of the amino acid sequence of three bacterial liquefying $\alpha$-amylases deduced from the DNA sequences, J. Biochem. 98 (1985) 1147-1156. 